\title{
TED TALKS: A GENRE ANALYSIS ${ }^{1}$
}

\author{
TED Talks: uma análise de gênero
}

\author{
José Augusto Simões de MIRANDA \\ Programa de Pós-Graduação em Inglês \\ Universidade Federal de Santa Catarina \\ joseaugustosimoesdemiranda@gmail.com \\ https://orcid.org/0000-0002-0057-1685 \\ Maria Ester Wollstein MORITZ \\ Programa de Pós-Graduação em Inglês \\ Universidade Federal de Santa Catarina \\ nicamoritz@yahoo.com \\ https://orcid.org/0000-0001-9848-9171
}

\begin{abstract}
This research aims at investigating TED Talks as a genre. The analysis focuses on its rhetorical structure, characterized by moves and steps and the communicative purposes of the genre. The corpus comprises 10 talks selected from the website TED Talks. The data are discussed in the light of Bhatia's (1996/2004) and Swales' (1990/2004) theories of genre. Results demonstrate that, in terms of the analysis of the rhetorical structure, it reveals a constant pattern of moves and steps along the corpus, since every talk contained the five moves identified by the analysis. These cyclical and more frequent moves are: topic introduction, speaker presentation, topic development, concluding messages, and acknowledgments/gratitude. In terms of its communicative purpose, TED aims to celebrate ideas to a diverse audience worldwide, due to the variety of topics encompassed. This study also allowed us to develop a deeper view of this spoken genre, its features, and the way individuals may benefit from it in their lives. KEYWORDS: TED Talks; Genre Analysis; Communicative Purpose; Rhetorical Convention.

RESUMO: Esta pesquisa visa investigar TED Talks como um gênero. A análise centra-se nos propósitos comunicativos do gênero, assim como a estrutura retórica, caracterizados por seus movimentos e passos. O corpus compreende 10 talks selecionados no site TED Talks. Os dados são
\end{abstract}

\footnotetext{
${ }^{1}$ This article presents the result of an unpublished Master's thesis. This research was funded by Coordenação de Aperfeiçoamento de Pessoal de Nível Superior (CAPES).
}

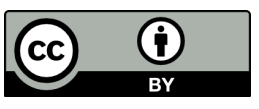


discutidos à luz das teorias da análise de gênero de Bhatia (1996/2004) e Swales (1990/2004). Os resultados demonstram que, em relação à análise da estrutura retórica, ela revela um padrão constante de movimentos e passos no corpus, uma vez que todo talk contém os cinco movimentos identificados na análise. Esses movimentos cíclicos e mais frequentes são: introdução do tema, apresentação dos emissores, desenvolvimento do tópico, mensagens de conclusão e agradecimentos. No que concerne ao propósito comunicativo, em função da diversidade de tópicos abrangidos, TED busca compartilhar ideias para uma audiência heterogênea e universal. Este estudo também nos permitiu desenvolver uma visão mais aprofundada desse gênero oral, bem como de suas características e a maneira com que as pessoas podem se beneficiar dele em suas vidas. PALAVRAS-CHAVE: Ted Talks; Análise de Gênero; Propósito Comunicativo; Convenção Retórica.

\section{INTRODUCTION}

Genre studies have gained significant status during the past decades (BAZERMAN, 2010; BONINI, 2001; MARCUSCHI, 2004; MARTIN, 1984; MEURER, 2003; MORITZ, 2006; SWALES, 1990; DUBOIS, 1980; THOMPSON, 1994; ROWLEY-JOLIVET; CARTER-THOMAS, 2005), and genres are present in different areas of human activity. For instance, in the field of law, there is the trial and the petition; in the police field, there is the police report and the infraction notice; in a domestic setting, there is the recipe and the supermarket list; and in school, there is the test, the presentation, and the written assignment (MORITZ, MATIELO; DELLAGNELO, 2015). According to Meurer (2003), it is within and through genres that humans both produce and challenge social reality.

According to Miranda (2018), in the last few decades - more specifically with the advent of the internet - new means of communication have appeared and, as a consequence, other channels for spreading information have been created and new genres are now evident. TED (Technology, Entertainment and Design) is one of the new ways of spreading information on the internet, and is a nonprofit organization devoted to spreading ideas in the form of short free talks, both online and on-site, and it also shares education lessons through the also well-known TED-EDs.

Caliendo (2014) points out that TED talks encompass a number of genre types, university lectures, newspaper articles, conference presentations and TV science programs, mixing different semiotic modes, including spoken, written, video and audio. Additionally, the author also claims that TED talks are a clear example of the way in which web-mediated popularization discourse has generated new genres, resulting from the 
influence of varied discursive and professional practices and purposes (e.g. informational, promotional and providing entertainment). Given the potential of the genre for spreading quality information within the reach of many people around the world, more research should be carried out on TED talks.

In this vein, this study aims to investigate the configuration of the genre TED talks. With this in mind, the general research question to be addressed is: How are TED talks configured as exemplars of the same genre? In order to answer such a question, the following two specific questions were designed: (1) What is the communicative purpose of TED Talks?; and (2) Which rhetorical configuration, in terms of moves and steps, characterizes TED talks as exemplars of the same genre?

The present article is divided into five sections: the first section introduces the study's main rationale as it explains what it is about, the reason behind the topic choice, and the study's significance; the second section discusses some literature on genre studies; the third section describes the procedures for data collection and analysis; the fourth section discusses the study's results; and the last section presents the study's main conclusions. The following section, thus, discusses the literature on genre studies.

\section{GENRE STUDIES}

Genres are part of different areas of human activities and they make part of people's daily lives whenever communication occurs. As stated by Nascimento (2009), genres have a central role in our lives as they mediate, represent and materialize language practices. Therefore, it's important to understand genres as social actions with a central role in our society as they regulate and orient social and discursive practices.

According to Bathia (2004), the study of genres has been carried out since Aristotle's Rhetoric. However, the author adds that it only became popular in the late 90 's and early 2000's, and it has emphasized discourse contextualization in social institutions such as commerce, government, and education since then. As claimed by Bhatia (1996), research on genre extends from discourse analysis to linguistic description, often trying to answer the following question: why do members of specific discourse communities use language the way they do? According to the author, such popularity of genre studies allowed more variations in interpretations, orientations and frameworks. Sometimes, these variations are so substantial and complex that one might find it difficult to recognize them as a single construct, or a uniform entity.

A seminal article written by Hyon (1996) mentions different approaches to genre studies. According to this scholar, three main traditions deserve attention: 
English for Specific Purposes (ESP), New Rhetoric (Reynolds, 1998), and a distinctive Australian approach that broadly draws on systemic functional linguistics. Although these traditions differ from one another regarding the theorists and practitioners, they still consist of similarities, such as the social, purposeful, and functional orientation to text construction (JOHNS, 2002).

One of the first important schools of genre, which originated in the USA, was motivated by writing teachers who taught rhetoric and writing courses which focused on studies of rhetorical traditions (BHATIA, 1996). According to the Rhetorical Genre Studies (RGS), genres are identified as typified social actions (BAZERMAN2010; MILLER, 1984).

The other major orientation to genre theory, known as the Australian School, sees genre as a staged, goal oriented social process (MARTIN, 1984). It started in Australia and it is rooted in systemic-functional linguistics (SFL) and social semiotics. This approach focuses on educational outcomes, particularly on the teaching and learning of economically and culturally disadvantaged school-age people in Australia (BHATIA, 1996).

The third orientation to genre theory, mentioned by Hyon - which is the focus of this research study - is the English for Specific Purposes (ESP), having Bhatia $(1996 / 2004)$ and Swales (1990/2004) as two of its most important scholars. It emerged in the U. K., in the 1960s, within the broader framework of discourse analysis for applied linguistic purposes, especially the teaching of English for specific purposes. It focuses on studying and teaching specialized varieties of English, most often to non-native speakers of the language, in advanced academic and professional settings (BHATIA, 1996). For ESP practitioners, a genre is seen as "a class of communicative events, therefore, the members of which share some set of communicative purposes" (SWALES, 1990, p. 58).

According to ESP scholars, mainly by John Swales, ESP genre investigation starts by identifying the communicative purpose of the genre so as to move on to an analysis of the genre's rhetorical structure. The communicative purpose is central to Swales' and his collaborators' approach. For Askehave and Swales (2001), apart from its importance, the concept is not easily identifiable. The authors give an example of a shopping list: even though the communicative purpose of the genre seems easy to recognize - help people remember what they should buy at the supermarket - its communicative purpose could also be primarily to impose discipline on people ('if not on the list, don't buy it'). A shopping list could also be another genre, such as a poem. Therefore, if two similar texts have different communicative purposes, they might be categorized under different genres. 
Regarding the communicative purposes of oral presentation activities in the English for General Purposes (EGP) courses, Chang and Huang (2015) point out that such activities do not have clear specific audiences, purposes, and communicative contexts. Also, according to them, there is not much literature available regarding instructions for oral presentations.

According to Swales, genre analysis consists of the investigation of the rhetorical structure of a genre in a determinate context. His Move Analysis describes moves that realize the writer's communicative purposes, and steps which are optional textual elements.

Swales' $(1990,2004)$ method of analyzing a genre started with his well-known research articles (RAs) introductions "creating a research space" (CARS) model of genre studies. For the analysis of research article introductions, the author first identifies the typical "moves" authors make within the introduction. A move has a specific purpose in a part of a text - which plays an important role to the communicative purpose of a genre - and, in a smaller part, its steps are found (CONNOR, UPTON; KANOKSILAPATHAM, 2007).

Swales' RAs introductions are characterized by three moves: I) "establishing a territory" (move 1); II) "establishing a niche" (move 2); III) "occupying the niche" (move 3 ). Each of these moves is realized by different steps that are also identified. In his last version of the "create a research space" (CARS) model of genre studies, Swales proposes the following (Swales, 2004, pp. 230-232):

MOVE 1 ESTABLISHING A TERRITORY (citations required) via

Topic generalizations of increasing specificity

MOVE 2 ESTABLISHING A NICHE (citations possible) via

Step 1A Indicating a gap or

Step 1B Adding to what is known

Step 2 (optional) Presenting possible justification

MOVE 3 PRESENTING THE PRESENT WORK (citations possible) via

Step 1 (obligatory) Announcing present research descriptively and/or purposively

Step 2* (optional) Presenting Research Questions (RQ) or hypotheses

Step 3 (optional) Definitional clarifications

Step 4 (optional) Summarizing methods 
Step 5 (PISF**) Announcing principal outcomes

Step 6 (PISF) Stating the value of the present research

Step 7 (PISF) Outlining the structure of the paper

Figure 1: Swales' CARS model (2004)

* Steps 2-4 are not only optional but less fixed in the order of occurrence than the others.

** PISF: Probable in some fields, but unlikely in others.

In the first move proposed by Swales, establishing a territory, citations are required, the importance of the research (optional) can be established and previous research (mandatory) must be introduced and reviewed. In the second move, establishing a niche, where citations are possible, a gap from previous research can be pointed out and new ideas/knowledge should be added. In the third move, presenting the present work, the niche will be occupied when the nature of the research study (mandatory) is provided, research questions and hypotheses (optional) are listed, the method (optional) is summarized, the principal outcomes are announced, the value of the research study is stated, and the structure of the paper is outlined. It is also important to bear in mind that although the moves and steps proposed by Swales in research articles increase specificity (from move 1 to move 3), they may be cyclical and vary among fields.

Many ESP/EAP scholars, including Swales himself, adopted Swales' model of rhetorical structure of introductions to also analyze spoken genres. However, according to Carter-Thomas and Rowley-Jolivet (2003), a methodological problem may be encountered in the analysis of spoken genres. Even though the analysis of written academic genres, such as RAs, for instance, in which sections are clearly identified introduction, review of literature, method, discussion, etc. - , the beginnings and endings of spoken genres seem to be less easily and clearly identifiable. Therefore, whereas they are clearly materialized in the RA, they might not be so evident in a spoken genre. Furthermore, spoken genres are more flexible than written genres, since the real-time and impromptu decisions of the speaker are visible, mainly in presentations, and the rules are far less codified (CARTER-THOMAS; ROWLEY-JOLIVET, 2003).

When it comes to spoken genres, Evans (2013) and Kim (2006) point out that the most common ones are seen in oral presentations of English-language learners and also belong to academic and workplace settings. On the other hand, Chang and Huang (2015) state that in those countries that individuals do not mostly speak English or it is not spoken in primary language in schools, a different approach, as English for General Purposes (EGP) plays an important role regarding the teaching of oral presentation skills and are mainly worked in universities. 
Thompson's (1994) analysis of lecture introductions across disciplines identified two moves: setting up the lecture framework and putting the topic into context. Other two move analyses of academic oral genres were carried out. Rowley-Jolivet and CarterThomas (2005) found that introductions of conference presentations were made up of three moves: setting up the framework, contextualizing the topic, and stating the research rationale. Chang and Huang's (2015) analysis of TED Talks revealed a move rhetorical structure consisting of seven moves: listener orientation, topic introduction, speaker presentation, topic development, closure, concluding messages, and acknowledgments/ gratitude. Such a structure emphasizes the flexibility of a non-linear ordering and nonobligatory occurrence of moves that are typically found in spoken genres (CHANG; HUANG, 2015).

It is important to mention that TED talks focus on scientific research and attempt to transmit scientific knowledge to a lay audience; therefore, they are a new way of popularization of science (SCOTTO DI CARLO, 2014). TED speakers, who might be either scholars or well-known people, adapt their speech in order to make it understandable to a wider variety of non-specialized public, which has little or no background in the topic broadcast (THEUNISSEN; CHAN, 2014).

While many science popularization genres are mediated by a journalist, who may create some distance between the scientific community and the audience, TED talk mediators are most often scientists who carry out research themselves (MIRANDA, 2018). Thus they provide the audience with knowledge about their own studies, which may bring the audience closer to their research.

\section{METHOD}

We selected 10 talks which were delivered by scientists to compose this study. The criteria to select the talks were: i) their main field - talks presented by the scientific community and that belong to the category of science; ii) their duration - 12 to 18 minutes long because it was the average time of our selection based on the first criterium; iii) the selection of the language of the talks was English; and iv) the speakers' reputationeach speaker's resume was investigated, and we ended up including scientists of wellknown universities worldwide.

The corpus was collected on the website: www.ted.com, in April, 2017, and they are listed as follow: 
1. A new way to study the brain's invisible secret

2. We can start winning the war against cancer

3. Your words may predict your future mental health

4. What makes a good life? Lessons from the longest study on happiness

5. What veterinarians know that physicians don't?

6. How to make hard choices?

7. What we can do to die well

8. How to make stress your friend

9. Txtng is killing language. JK!!!

10. Meet your microbes

The study was carried out following a qualitative research method and is discussed in the light of Swales's and Bhatia's theories on Genre Analysis. According to Miranda (2018), since these theoreticians are notable in the ESP genre orientation, the investigation of this research followed some of the main steps for ESP genre analysis, starting with the identification of the communicative purpose of the selected talks, and then moving on to an analysis of the genre's rhetorical moves and steps.

Swales (1990) points out that a genre comprehends communicative purposes, which are identified by individuals of the target discourse community. Although recognizing the communicative purpose of a genre is not an easy task and sometimes it is not clearly found in the genre, we could verify its existence by taking into consideration Swales (1990)'s concept, in which social interactions are materialized as a discourse and the existence of meaningful mutual goals is perceived. We have also considered the author's move-step approach, in which the moves provide the intentions of the communicative purposes.

Based on the aforementioned, the communicative purpose of the present research was analyzed and our evidences while watching the talks have served as a starting point. It is important to bear in mind that the corpus as a whole, as its main field and the content of the talks, were taken into consideration in order to carry out this investigation. Also, those evidences were realized from the talks' mutual goals, as well as the information presented in the website.

In order to answer the second research question, the rhetorical structure - which included the rhetorical moves and steps identified in the samples —, other four studies were taken into consideration (SWALES, 1990/2004; THOMPSON, 1994; ROWLEYJOLIVET; CARTER-THOMAS, 2005; CHANG; HUANG, 2015). 
We firstly randomly selected two talks, watched and piloted them. Then, we read the transcripts and applied the move rhetorical structure identified by the studies aforementioned. Afterwards, we compared and carried out a careful analysis on differences and similarities of the moves and steps' configuration, as well as modified by including or excluding others move types when necessary. We also analyzed whether or not the existence of cyclical or obligatory moves and steps was found in the corpus selected.

Regarding textual analysis, we took into consideration text-patterning and lexicogrammatical features in order to analyze the moves and steps (BAWARSHI; REIFF, 2010). Textual signals were used and identified in our data: i) explicit lexemes, in which the content and function of the moves, as well as the constitution of the whole text, are signaled by words (NWOGU, 1990); ii) validity markers, in which textual clues are used in order to express the speakers judgment, as perhaps, may, probably, can (VANDE KOPPLE, 1985); and iii) summary statements, which are used to conclude sentences, as to sum up (NWOGU, 1990). Regarding the transcripts of the talks, they are already available in each TED talks on the website. In the following sections, the results of the research are presented.

\section{RESULTS}

The results presented in this section deals with the overall findings of the communicative purpose as well as the comprehension of the outcome of the rhetorical organization characterized by the moves and steps of the talks analyzed.

When it comes to the investigation of the communicative purposes, there were two analyzes which were taken into account: i) the examination displayed on the website in order to identify the texts materialized in the talks presented by the speakers; and ii) the researchers' evidences while watching the talks, which were based on the literature discussed.

According to TED's website, TED is a global community, which invites individuals from different areas and cultural backgrounds to better understand global issues. TED's organizers believe that the presenters interact with the audience by teasing individuals in the sense of giving them the chance to be in contact with other individuals that hold different world views in order to deconstruct preconceived ideas. Also, according to them, all the events provided, such as Conferences, TED Talks, projects developed by the TED Prize, TEDx community, and TED-Ed lesson series, aim at spreading ideas all over the world. 
As previously discussed, when it comes to oral genres, Chang and Huang (2015) argue that English for General Purposes (EGP), which is a teaching approach, comprehend a wider category that is not specific to academic and professional contexts. They complement that EGP are concerned with genres that do not present clear purposes, contexts, and audiences. Since TED talks are considered a science popularization genre, they do not belong to academic and professional contexts, and therefore, they lack clear (communicative) purposes and audiences.

In order to analyze the communicative purposes of the talks, it is important to bear in mind that the talks are delivered by researchers of certain fields, who are expert on the content broadcast and demonstrate professional skills - which somehow come from their scientific knowledge (MIRANDA, 2018). Due to the range of topics available on the list, the audience may watch the talks from areas they are not knowledgeable about, as well as better understand some field they are already familiar with.

Based on the aforementioned - the information presented on the website, as well as the researchers' evidences while watching the talks, and the limitation of clear purposes that this type of genre provides - it is possible to assert that TED's communicative purpose is to celebrate ideas to a diverse audience worldwide (MIRANDA, 2018). Also, TED's motto "Ideas worth spreading" converges the researchers' investigation previously discussed.

Regarding "private intentions" claimed by Bhatia (2012), it is possible to assert that besides displaying information and knowledge to a diverse public, TED speakers also aim at promoting their research, as well as revealing their professional image. This intention was also noticed while carrying out the analyses.

When it comes to the investigation of the rhetorical organization, Jolivet and Carter-Thomas (2003) state that a move analysis was firstly used to investigate written texts, instead of oral ones. According to the authors, the outset of spoken genres is not clearly and easily identified due to fact that they do not provide clear endings and beginnings of sections. Apart from the difficulties, over the years, the approach has also been used to investigate oral monologues.

As previously stated, we took into consideration four studies (SWALES, 1990/2004; THOMPSON, 1994; ROWLEY-JOLIVET; CARTER-THOMAS, 2005; CHANG; HUANG, 2015) in order to identify the rhetorical organization of the talks investigated. From the four studies taken into account, we could only identify moves established in Chang and Huang's (2015) research study, as it was expected, due to the fact that it is specifically about TED talks. Their study analyzed 58 TED talks and the 
authors found out five obligatory moves: topic introduction, topic development, closure, concluding messages, and acknowledgments/gratitude, and two non-obligatory moves: listener orientation, and speaker presentation (MIRANDA, 2018).

The move analysis in the present study established five obligatory moves and their corresponding steps: topic introduction, speaker presentation, topic development, concluding messages, and, acknowledgments/gratitude. All the five moves were also found in Chang and Huang (2015) analysis. However, different from their study, we have not found non-obligatory moves in any of the talks. All the five moves were encountered in $100 \%$ of the corpus. According to Kanoksilapatham (2007), moves which occur in $60 \%$ of the corpus are considered obligatory. Also, the moves are cyclical, that is, they appear more than once in the talks, but mainly following the order presented in Table 1.

Table 1: Moves and Steps in TED Talks.

\begin{tabular}{|l|c|}
\hline \multicolumn{1}{|c|}{ Move } & Step $\quad$ Frequency (\%) \\
\hline 1. Topic introduction & $\begin{array}{c}\text { Set the scene (90\%) } \\
\text { Announce the topic (80\%) }\end{array}$ \\
\hline 2. Speaker presentation & $\begin{array}{c}\text { Establish authority (70\%) } \\
\text { Show stance/position (90\%) }\end{array}$ \\
\hline 3. Topic development & $\begin{array}{c}\text { Present an argument (90\%) } \\
\text { Offer an explanation (100\%) }\end{array}$ \\
\hline 4. Concluding messages & Call for action (100\%) \\
\hline 5. Acknowledgements/gratitude & Make generalization/offer speculation (90\%) \\
\hline
\end{tabular}

Source: Miranda (2018, p. 46)

*According to Table 1, moves 1, 2, 3 and 4 encompassed steps, which are realizations of moves and move 5 did not include steps. Although the moves were found in all the 10 talks $(100 \%)$, as previously discussed, the steps were not. For example, in move 1, the first step "set the scene" was found in 9 talks $(90 \%)$, the second step "announce the topic" was found in 8 talks $(80 \%)$, and so on, as described below.

According to Chang and Huang (2015), the topic introduction move presents the topic to the viewers, and the 10 talks analyzed in the present study started with this move. They were realized by two steps: set the scene, in which the authors provide background Revista X, v. 16, n. 6, p. 1552-1573, 2021. 
information (e.g. what has been going on in the speaker's life or with certain groups of people) and therefore establish the rationale for the talk. In the step Announce the topic, some speakers present the topic directly, while others try to paraphrase it (CHANG; HUANG, 2015). The first step, set the scene, was found in 9 talks (in $90 \%$ of the talks), and an example is displayed as follows:

But what we're trying to do in my group at MIT is to figure out if we can do something similar to the brain. Can we make it bigger, big enough that you can peer inside and see all the tiny building blocks, the biomolecules, how they're organized in three dimensions, the structure, the ground truth structure of the brain, if you will? If we could get that, maybe we could have a better understanding of how the brain is organized to yield thoughts and emotions and actions and sensations. Maybe we could try to pinpoint the exact changes in the brain that result in diseases, diseases like Alzheimer's and epilepsy and Parkinson's, for which there are few treatments, much less cures, and for which, very often, we don't know the cause or the origins and what's really causing them to occur. Now, our group at MIT is trying to take a different point of view from the way neuroscience has been done over the last hundred years. We're designers. We're inventors. We're trying to figure out how to build technologies that let us look at and repair the brain. And the reason is, the brain is incredibly, incredibly complicated. (Excerpt 1 - TED 1) $)^{2}$

"In this talk, neuroengineer Ed Boyden reveals he wants to know how the tiny biomoleculesin ourbrains generateemotions, thoughts and feelings - and also themolecular changes that lead to disorders like epilepsy and Alzheimer's" (MIRANDA, 2018, p. 47).

In Excerpt 1, Miranda (2018) states that the speaker mentions what a certain group of people is doing or trying to do - in their Massachusetts Institute of Technology (MIT) group: But what we're trying to do in my group at MIT, and along the passage, it is noticed the use of the first person plural, which demonstrated more than one person, and specifically in this context, a particular group of people/researchers: We 're designers. We're inventors. We're trying to figure out how to build technologies that let us look at and repair the brain.

Moving to the second step of move 1, Announce the topic was present in 8 talks, and is demonstrated in the following excerpt:

\footnotetext{
${ }^{2}$ Examples in the analysis are signaled according to the appearance in the text and number of the talk. Therefore, Excerpt 1, refers to the first example that is presented in this article while TED 1 refers to the first TED talk mentioned in the method section.
} 
Here I'd like to propose that in the same way we can reconstruct how the ancient Greek cities looked just based on a few bricks, that the writings of a culture are the archaeological records, the fossils, of human thought. (Excerpt 2 - TED 3)

"In this talk, neuroscientist Mariano Sigman reflects on ancient Greece and the origins of introspection to investigate how words hint at people's inner lives, as well as details a word-mapping algorithm that could predict the development of schizophrenia" (MIRANDA, 2018, p. 48). According to the author, it is possible to notice in the passage how the speaker presents the topic, in other words, what he would like to propose with that talk: Here I'd like to propose that.

The second move identified in the analysis is the speaker presentation. According to Chang and Huang (2015), the speaker presentation move allows the audience perceives the relationship between the presenter and the topic and his/her background is also displayed. This move is composed of two steps, establish authority and show stance/position. The first one is concerned with presenting the speaker's achievements, credentials, and knowledge during the talk (CHANG; HUANG, 2015). And the second one, show stance/position, demonstrated the speaker's attitude under the topic discussed (CHANG; HUANG, 2015). The first step was observed in 7 talks, and an example is displayed in the following excerpt:

We did that. The Harvard Study of Adult Development may be the longest study of adult life that's ever been done. For 75 years, we've tracked the lives of 724 men, year after year, asking about their work, their home lives, their health, and of course asking all along the way without knowing how their life stories were going to turn out. Studies like this are exceedingly rare. Almost all projects of this kind fall apart within a decade because too many people drop out of the study, or funding for the research dries up, or the researchers get distracted, or they die, and nobody moves the ball further down the field. But through a combination of luck and the persistence of several generations of researchers, this study has survived. About 60 of our original 724 men are still alive, still participating in the study, most of them in their 90 s. And we are now beginning to study the more than 2,000 children of these men. And I'm the fourth director of the study. (Excerpt 4 - TED 4)

It is possible to notice that the speaker also talks about a group of people, however, it was considered the establish territory step within the speaker presentation move, due to the salient achievements stated, as well as the importance and relevance of the study which were also clearly emphasized (MIRANDA, 2018). The scientist states: studies like 
this are extremely rare. Almost all project of this kind fall apart within a decade because... It was possible to notice that the speaker also asserted his credentials in delivering the talk when he mentioned "The Harvard Study of Adult Development".

As for the second step, show stance/position, it was observed in 9 talks, and an example is shown in the following excerpt:

Now, the good news, they said, is that there are tons of different treatments to choose from, but the bad news is that in order for them to tell if a treatment is even working or not, well, that takes them about three months or so. So they cannot try that many things. (Excerpt 5 $T E D$ 2)

In this passage, the speaker shows his position concerning the topic, explaining his attitude toward it by stating the pros and cons: Now, the good news, they said, is that there are tons of different treatments to choose from, but the bad news is that in order for them to tell if a treatment is even working or not, well, that takes them about three months or so. Since the topic of the talk is the war against cancer, the speaker firstly shows his position talking about the different possibilities of treatments, as being something positive, but he also demonstrated a skeptical side in relation to the time a patient may have to wait when he/she has only 12 months to live, for instance (MIRANDA, 2018).

The third move identified in the corpus is the topic development move. According to Chang and Huang (2015), during this move, the explanation, description, and support of the topic is realized by the speaker. The move is realized by three steps: present an argument, offer an explanation, and describe a process/series of events. According to the authors, there may be an emotional appeal used by the speaker while presenting arguments, as well as logical evidences in order to invite the tease the audience to reflect about different perspectives. Offer an explanation was a cyclical step as it appears in different times during the talk, and a new idea, object, trend, or concept under discussion are explained, as well as examples, statistical details, and analogies that may be used by the speakers (CHANG; HUANG, 2015). According to the authors, describe a process/ series of events occurs when the speaker explain how something is realized step by step, for instance. The step present an argument was observed in 9 talks, and an example is shown in the following excerpt:

Self-injury. Some human patients harm themselves. Some pluck out patches of hair, others actually cut themselves. Some animal patients also harm themselves. There are birds that pluck out feathers. There are stallions that repetitively bite their flanks until they bleed. But 
veterinarians have very specific and very effective ways of treating and even preventing self-injury in their self-injuring animals. Shouldn $>t$ this veterinary knowledge be put into the hands of psychotherapists and parents and patients struggling with self-injury? (Excert 6 - TED 5)

In excerpt 6, there was an emotional appeal when the speaker talks about selfinjury: Self-injury. Some human patients harm themselves. Some pluck out patches of hair, others actually cut themselves. Some animal patients also harm themselves. Regarding the question posed at the end of the passage, Miranda (2018) points out that the speaker also invites the audience to new ways of thinking, as well as tries to deconstruct the viewer's thoughts, as she provides the chance for perspective change in the topic under discussion: Shouldn't this veterinary knowledge be put into the hands of psychotherapists and parents and patients struggling with self-injury?

The second step, Offer an explanation, was identified in all the 10 talks and an example is displayed as follows:

As history has gone by, it's been natural for there to be a certain amount of bleed between speech and writing. So, for example, in a distant era now, it was common when one gave a speech to basically talk like writing. So I mean the kind of speech that you see someone giving in an old movie where they clear their throat, and they go, "Ahem, ladies and gentlemen," and then they speak in a certain way which has nothing to do with casual speech. It's formal. It uses long sentences like this Gibbon one. It's basically talking like you write, and so, for example, we're thinking so much these days about Lincoln because of the movie. The Gettysburg Address was not the main meal of that event. For two hours before that, Edward Everett spoke on a topic that, frankly, cannot engage us today and barely did then. The point of it was to listen to him speaking like writing. Ordinary people stood and listened to that for two hours. It was perfectly natural. That's what people did then, speaking like writing. (Excerpt 7 - TED 9)

In this passage, examples were used to explain and guide the audience when he says: so, for example, in a distant era now, It was common when one gave a speech to basically talk like writing... and so, for example, we're thinking so much these days... signaling the step "offer an explanation" (MIRANDA, 2018).

The third step, describe a process/series of events was present in 9 talks. One example is displayed in the following excerpt:

Well, unfortunately, three months later, we got the news, it didn't work. And so Ehud goes into his second treatment. And again, the same 
story. «It feels so bad, something's gotta be working there." And then three months later, again we get bad news. Ehud is going into his third treatment, and then his fourth treatment. And then, as predicted, Ehud dies. (Excerpt 8 - TED 2)

In this step, the speaker time is taken into consideration, which guides the audience and therefore describes a process/series of events (MIRANDA, 2018). In the passage above, the step was demonstrated by textual clues, such as so, then, and then, which evidence a sequence, as used in Jolivet and Carter-Thomas's (2005) study.

The next move identified in the corpus is called concluding messages. According to Chang and Huang (2015), in this move, the purpose of the talk is raised, often trying to answer the "so what" question, and two possible steps are provided: call for action and make a generalization/offer speculation. The authors state that it is common for speakers to let their audience know how they are expected to think and act after the talk by making a call for action. In the second step make a generalization/offer speculation, the speakers aim at offering new , as well as presenting broader (e.g., to the world, a larger community, or a discipline), or tease the audience to think more about the ideas presented (CHANG; HUANG, 2015). One example of the step call for action that was found in all the 10 talks is displayed as follows:

Far from being sources of agony and dread, hard choices are precious opportunities for us to celebrate what is special about the human condition, that the reasons that govern our choices as correct or incorrect sometimes run out, and it is here, in the space of hard choices, that we have the power to create reasons for ourselves to become the distinctive people that we are. And that's why hard choices are not a curse but a godsend. (Excerpt 9- TED 6)

In this passage, the speaker "calls for action" by deconstructing the problem of hard choices in individuals' lives, as well as the audience is invited to think and act differently with this concluding message (MIRANDA, 2018). The author states that by trying to offer different perspectives to face hard choices, the speaker makes the audience reflect on their decisions, the cause of their anxiety, and psychological conflicts: Far from being sources of agony and dread, hard choices are precious opportunities for us to celebrate what is special about the human condition.

For the second step make a generalization/offer speculation, which was observed in 9 talks, an example is displayed in the following excerpt: 
To my colleagues, to my patients, to my government, to all human beings, I ask that we stand and we shout and we demand the best care possible, so that we can live better today and ensure a better life tomorrow. We need to shift today so that we can live tomorrow. (Excerpt 10 - TED 7)

In Excerpt 10, new possibilities the speaker in order to encourage listeners to think about the ideas presented, also, he highlights the importance of those ideas and urges change regarding our quality of life in the talk named "what we can do to die well" when he says: to my colleagues, to my patients, to my government, to all human beings, I ask that we stand and we shout and we demand (MIRANDA, 2018).

The final move identified in the current study is acknowledgements/gratitude. Chang and Huang (2015) points out that speakers acknowledge or pay compliments to their audience, or show appreciation for the opportunity to be invited to speak at TED. They were observed in all the 10 talks, as the example shows:

Thank you. (Excerpt 11 - TED 8)

It is possible to notice that all the speakers express gratitude for being at TED talks and presenting the talks for their audience. Excerpt 11 shows this appreciation (all the other occurrences are similar to this one).

As previously stated, the present study analyzed the communicative purpose, and the rhetorical structure - often characterized by the rhetorical moves and steps it undertakes - of 10 TED Talks. The communicative purposes were identified through the website, and the researchers' evidences while watching the talks and reading the target literature. Five moves (and their component steps) were identified. In Chang and Huang's (2015) study, it was investigated the rhetorical organization of 58 talks and found seven move types (and their component steps), concluding that a genre prototype was established.

Although some similarities regarding moves and steps of the present research with Chang and Huang's (2015) study, there are also some differences. While the authors found five obligatory moves and two non-obligatory moves, we could identify five obligatory moves. Also, the obligatory move closure and the non-obligatory move listener orientation were not found in our study, and the move speaker presentation found in the present investigation was non-obligatory in Chang and Huang's (2015), therefore, the prototype established by these authors differs in the previous features of the present study. We suggest that the reason these differences occur is that the present study 
specifically belongs to the category of science, different from Chang and Huang's (2015), that comprised different fields.

\section{FINAL REMARKS}

This research aimed at making contributions to a richer understanding of the nature of TED Talks, as they have become important events for creating and sharing knowledge. Since individuals watch their talks worldwide because of their relevance with a great variety of topics, TED Talks have expanded their audience over the years, becoming really popular. Also, understanding their nature may contribute to a richer understanding of the social and contextual functions of the genre. In addition, by examining and explaining the configuration of the genre, the study will hopefully extend existing knowledge in the field.

In order to identify the communicative purpose of the TED talks selected for the analysis, firstly, the information displayed on the website was analyzed. In this vein, the organizers claim that those speakers are important researchers and, therefore, are able to contribute to their audience in order to raise different ideas and perspectives which offer the possibility of change, as well as mechanisms to make the world a better place to live in.

According to Bhatia (2012), however, a more critical vein is approached, in which TED researchers also have other intentions, as trying to improve their images as scientists, rather than merely attempting to provoke change in the audience's perspective, as previously discussed.

After analyzing the corpus, it was noticed that regardless of the intention, while presenting the talks, TED speakers can make their audience knowledgeable and/or informed. By watching the talks, viewers are able to benefit from the topics presented. As the talks provide a range of topics, TED's communicative purpose is to celebrate ideas to a diverse public worldwide. Due to the heterogenous audience, TED's motto "Ideas worth spreading", therefore, aims at summarizing the investigation of the communicative purpose, which consists in celebrating new ideas and research, designed mainly for a lay audience.

Regarding the rhetorical structure - characterized by the moves and steps it undertakes - of those TED talks, the present study established five obligatory move types and their corresponding steps, all the five moves being encountered in $100 \%$ of the corpus. The moves are also cyclical, that is, they appear more than once in the talks, but mainly following one specific order described in the results.

As they have become popular over the years, a number of topics have been incorporated and more viewers are able to explore new fields through the talks presented. 
It is also worth mentioning that this genre allows individuals to benefit from it while delivering oral presentations, for instance: in short, the rhetorical organization of this genre given by academics follows patterns which leaners can follow, and together with other features analyzed along the study, the genre can contribute to speakers' performance when they deliver a presentation.

Regarding limitations of the study, we are aware of the reduced number of talks only 10 - as well as the lack of studies specifically for TED talks, which lacks literature. Also, the scope of the investigation itself was another limitation. The initial idea was also to analyze the discourse community of the genre, however since it was not possible to identify all the audiences, we decided to focus on the rhetorical organization and the communicative purposes of the genre. When it comes to communicative purposes, as pointed out by the corresponding literature, there are not clear ones in this type of genre - which may also be considered a limitation of the study.

For future research, we suggest the analyses of TED talks given by speakers from different areas, as non- scholars, actors/actresses; singers; athletes; among others.

\section{REFERENCES}

ASKEHAVE, I ; SWALES, J. M. Genre identification and communicative purpose: a problem and a possible solution. Applied Linguistics, 2001, p. 195- 212.

BAWARSHI, A.S; REIFF, M. J. Genre: an introduction to history, theory, research and pedagogy. Parlor Press and The WAC Clearinghouse, 2010.

BAZERMAN, C. The Informed Writer, The WAC Clearing House, 2010.

BHATIA, V. K. Methodological issues in genre analysis. Hermes - Journal of Linguistics, 1996, 16: 39-59.

BHATIA, V. K. Worlds of Written Discourse: A Genre-Based View. London: Continuum, 2004.

BHATIA, V. K. Critical Reflections on Genre Analysis. In Ibérica 24, 2012, 17-28.

BONINI, A. Ensino de Gêneros Textuais: A Questão das Escolhas Teóricas e Metodológicas. Trab. Ling. Apl., Campinas, (37):7-23, Jan./Jun. 2001. 
CALIENDO, G. The Popularization of Science in Web-Based Genres. In Bongo, Giancarmine/Caliendo, Giuditta (eds.), The Language of Popularization: Theoretical and Descriptive Models/Die Sprache der Popularisierung: Theoretische und Deskriptive Modelle. Bern: Peter Lang, 2014, 101-132.

CHANG, Y; HUANG, H-T. Exploring TED talks as a pedagogical resource for oral presentations: A corpus-based move analysis. English Teaching \& Learning, 39(4), 2015, 29-62. (THCI Core).

CONNOR, U., UPTON, T. A.; KANOKSILAPATHAM, B. Introduction to move analysis. In D. Biber, U. Connor, \& T. A. Upton (Eds.), Discourse on the move: Using corpus analysis to describe discourse structure (pp. 23-41). Amsterdam, The Netherlands: John Benjamins, 2007.

DUBOIS, B. Genre and structure of biomedical speeches. Forum Linguisticum Vol. V, 140-168, 1980.

EVANS, S. "Just wanna give you guys a bit of an update": Insider perspectives on business presentations in Hong Kong. English for Specific Purposes, 32, 195-207, 2013.

HYON, S. Genre in three traditions implications for ESL. TESOL Quarterly, 30(4), 693-722, 1996.

JOHN A. M. Destabilizing and enriching novice studentse genre theories. In A. M. Johns (Ed), Genre in the classroom: multiple perspectives (pp. 237-248). Lawrence Erlbaum Associates: Mahwahn, NJ, 2002.

KANOKSILAPATHAM, B. Rhetorical moves in biochemistry research articles. In D. Biber, U. Connor, \& T. A. Upton (Eds.), Discourse on the move: Using corpus analysis to describe discourse structure (pp. 73-119). Amsterdam, The Netherlands: John Benjamins, 2007.

KIM, S. Academic oral communication needs of East Asian international graduate students in non-science and non-engineering fields. English for Specific Purposes, 25, 479-489, 2006.

MARCUSCHI, L. A. Gêneros textuais emergentes no contexto da tecnologia digital. In: Marcuschi, Luiz Antônio; XAVIER, Antônio Carlos (Org.). Hipertexto e gêneros digitais: novas formas de sentido. Rio de Janeiro: Lucerna, 2004, pp. 13-67, 2004.

MARTIN, J. R. Language, register and genre. In F. Christie (Ed.), Children writing: Reader (pp. 21-29). Geelong, Victoria, Australia: Deakin University Press, 1984. 
MEURER, J. L. Genre as diversity, and rhetorical mode as unity in language use. Ilha do Desterro, Florianópolis, v. 43, 2003.

MILLER, C. Genre as social action. In Freeman \& Medway, (Eds) Genre and new rhetoric. London: Taylor \& Francis Ltd, 1984.

MIRANDA, J. A. S. TED Talks: a genre analysis. Dissertação (mestrado) - Universidade Federal de Santa Catarina, Centro de Comunicação e Expressão, Programa de PósGraduação em Inglês: Estudos Linguísticos e Literários, Florianópolis, 2018.

MORITZ, M. E. W. A contrastive genre study of conclusions as components of research articles across PL1, EL1 and EL2. Tese (doutorado) - Universidade Federal de Santa Catarina, Centro de Comunicação e Expressão, Programa de Pós-Graduação em Inglês: Estudos Linguísticos e Literários, Florianópolis, 2006.

MORITZ, M. E. W.; MATIELO, R; DELLAGNELO, A. K. Gêneros textuais e produção escrita em livros didáticos de português para estrangeiros: uma análise do livro Muito Prazer - Fale o Português do Brasil. In Silveira, R.; Emmel, I. (Orgs.) Um Retrato do Português como Segunda Língua: Ensino, Aprendizagem e Avaliação. 1.. ed. Campinas: Pontes, v. 1. (p.33-56), 2015.

NASCIMENTO, E. L. (Org.) Gêneros textuais: da didática das línguas aos objetos de ensino. São Carlos: Claraluz, 2009.

NWOGU, K. N. Discourse variation in medical texts: schema, theme and cohesion in professional and journalistic accounts. Monographs in Systemic Linguistics, 2. Nottingham: University of Nottingham, 1990.

REYNOLDS, M. Genre Analysis: what is it and what can it do? In Barsa Journal, 1(2), 1998.

ROWLEY-JOLIVET, E.; CARTER-THOMAS, S. Analysing the scientific conference presentation (CP), A methodological overview of a multimodal genre, 2003.

ROWLEY-JOLIVET, E.; CARTER-THOMAS, S. The rhetoric of conference presentation introductions: Context, argument and interaction. International Journal of Applied Linguistics, 15, 45-70, 2005.

SCOTTO DI CARLO, G. New trends in knowledge dissemination: TED Talks. Acta Scientiarum. Language and Culture, 36 (2), 121-130, 2014.

SWALES, J. M. Genre Analysis: English in Academic Research and Writings. Cambridge University Press: Cambridge, 1990. 
SWALES, J. M. Research genres: explorations and applications. Cambridge: Cambridge University Press, 2004.

THEUNISSEN, G.; CHAN, D. Analysis of the visual channel of communication in a corpus of TED Talks presentations. Master in de Meertalige Communicatie. Faculteit Letteren \& Wijsbegeerte. Universiteit Gent, 2014.

THOMPSON, S. Frameworks and contexts: A genre-based approach to analyzing lecture introductions. English for Specific Purposes, 13, 171-186, 1994.

VANDE KOPPLE, W. J. Some exploratory discourse on metadiscourse. College Composition and Communication, 36(1), 82-93, 1985.

Received: 22 July 2021. Accepted: 23 September 2021. 